\title{
Pregnancy and Lactation in a Patient with Gaucher Disease Receiving Enzyme Replacement Therapy: Case Report
}

\author{
Enzim Replasman Tedavisi Alan \\ Gaucher Hastasında Gebelik ve Laktasyon
}

\author{
Engin KORKMAZER, \\ Neşe SOLAK, ${ }^{b}$ \\ Vehbi Yavuz TOKGÖZ \\ aDepartment of Gynecology and Obstetrics, \\ Giresun University Faculty of Medicine, \\ ${ }^{\mathrm{b}} \mathrm{Clinic}$ of Gynecology and Obstetrics, \\ Giresun Maternity Hospital, \\ Giresun \\ cClinic of Gynecology and Obstetrics, \\ Kızltepe Public Hospital, \\ Mardin \\ Geliş Tarihi/Received: 08.09.2014 \\ Kabul Tarihi/Accepted: 08.12.2014 \\ Yazıșma Adresi/Correspondence: \\ Engin KORKMAZER \\ Giresun University Faculty of Medicine, \\ Department of Gynecology and Obstetrics, \\ Giresun, \\ TÜRKIYE/TURKEY \\ ekorkmazer@yahoo.com
}

\begin{abstract}
Gaucher disease (GD) is a lysosomal storage disorder characterized with beta-glucocerebrosidase enzime deficiency. The disease is progressive with several manifestations including hematologic abnormalities, organomegaly and bony abnormalities. Pregnancy may excerbate this manifestations. Enzyme replacement therapy (ERT) has been used to improve clinical signs and reverse organomegaly and disease progress. Studies showed that ERT with imiglucerase reduce the risk of abortion and GD related complications. However, there have been only a few published data regarding the effects of imiglucerase on fetus, on newborn and on infant. In this case we report a succesfull pregnancy, delivery and healthy 2-year follow-up of GD under ERT with imiglucerase.
\end{abstract}

Key Words: Pregnancy; Gaucher disease; imiglucerase; enzyme replacement therapy

ÖZET Gaucher hastalığı beta-glukoserebrozidaz enzim defektiyle karakterize bir lizozomal depo hastalığıdır. Hastalık ilerleyici şekilde seyreden hematolojik anormallikler, organomegali ve kemik hastalıkları gibi bulguları içeren çeşitli şekillerde ortaya çıkabilir. Gebelik bu tabloları ağırlaştırabilir. Enzim replasman tedavisinin hematolojik bozukluklar ve organomegali üstüne kayda değer iyileşme sağladığı gösterilmiştir. Çalışmalar imigluseraz ile yapılan enzim replasman tedavisinin gebelikte düşük ve Gaucher hastalığına bağlı komplikasyon oluşma riskini azalttığını göstermiştir. Bununla birlikte, imigluseraz kullanımının fetüs, yenidoğan ve çocukluk çağı üzerine etkisini gösteren az sayıda çalışma bulunmaktadır. Biz de bu vakamızda imigluseraz kullanan bir Gaucher hastasında gebelik, doğum ve 2 yıllık izlemini paylaştık.

Anahtar Kelimeler: Gebelik; Gaucher hastalığı; imigluseraz; enzim yerine koyma tedavisi

Turkiye Klinikleri J Gynecol Obst 2015;25(3):224-6

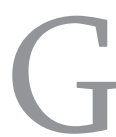

aucher Disease (GD) is an autosomal-recessively lisosomal storage disease characterized with beta-glucocerebrosidase enzime deficiency. ${ }^{1}$ It occurs in approximately 1 in 75,000 births world wide, but is more prevalent in individuals of Ashkenazi-Jewish descent., ${ }^{2,3}$ That deficiency leads to accumulation of glucocerebroside in monocytes and macrophages. Haematologic abnormalities (anemia, trombocytopenia, leucopenia), organomegaly and bony abnormalities (osteopenia, osteoporosis, etc.) are the characteristic clinical findings. ${ }^{4}$

Pregnancy may exacerbate the GD. Risk of peripartum and postpartum hemorrhage are increased due to trombocytopenia. ${ }^{5}$ Enzyme replacement 
therapy (ERT) with recombinant form "imiglucerase" has been found to improve clinical signs and reverse organomegaly. ${ }^{6} \mathrm{~A}$ follow-up study highlited safety of imiglucerase in pregnancy. ${ }^{5}$ Here we report a succesful pregnancy, delivery and 2 year follow up of a singleton pregnancy with GD.

\section{CASE REPORT}

A 31-year old female was diagnosed GD ten years ago based on chronic fatigue, abnormal blood count hepato-splenomegaly and presence of Gaucher Cells on bone marrow aspiration. She had splenectomy five years ago. Disease severity was scored as moderate and she has been referred to our obstetrics unit for pregnancy desire. She was taking ERT (imiglucerase) $30 \mathrm{U} / \mathrm{kg}$ body weight (bw) (1800 U) in every 2 weeks. In the light of literature we did not interrupt ERT. Pregnancy was confirmed 5 months later from pregnancy desire. She continued ERT (30 u/kg bw) during pregnancy in every two weeks. She was monitored in high risk pregnancy unit at our institution during pregnancy and postpartum period. At each visit the patient under went assessment for signs and symptoms, spesific physical examination, fetal sonogram, maternal complete blood cell count, maternal Vitamin D level measurement, maternal vitamin B12 level measurement and spesific areas of concern were individually examined (hematologist, gastroenterologist, orthopedic specialist). According to serum iron and percentage transferrin receptor saturation, multi-vitamin, calcium (1000 mg/day) and iron supplementation were taken by patient. She didn't accept prenatal diagnose for GD. She had mild trombocytopenia $\left(60000-100000 / \mathrm{mm}^{3}\right)$ duringpregnancy. At the $39^{\text {th }}$ week of gestation she have had a planned cesarean section ansection because of breech presentation (APGAR scores 9 at $1^{\text {th }}$ minute, 10 at $5^{\text {th }}$ minute; $3090 \mathrm{~g}$ ). No intra- or postpartum complication occured. Blood loss during cesarean was $450 \mathrm{~mL}$. Maternal platelet count was 210 000/mm $\mathrm{mm}^{3}$ one week after surgery. Depending on literature review, we allowed to breast feeding and decided to continue ERT during lactation. The patient recovered well from labor and the baby continued to healthy development. We observed baby for 2 years based on pediatricians evaluations.

\section{DISCUSSION}

Monitoring in pregnancy should be adapted to the needs of patient and clinical status of GD. Clinicians are advised to concentrate on bone involvement and trombocytopenia. A multidisciplinary approach to the management of pregnancy is desirable.

ERT with imiglucerase is well established and effective method in the treatment of GD. ${ }^{7}$ There is still no guideline for imiglucerase treatment during pregnancy and lactation. Elstein at al. reported live birth rate was $86 \%$ in ERT group. ${ }^{5}$ Post-partum bleeding is the most serious problem of GD. These women should be considered at high risk, and blood, fresh frozen plasma and adequte surgical conditions should be available at delivery. ERT does not seem to reduce the risk of post-partum bleeding. ${ }^{5}$ But data is insufficent to decide about this subject. Effect of ERT with imiglucerase on fetus has not been well documented and hence there are some difficulties about to prescribe this drug during pregnancy. No adverse effect reported yet on fetus in the literature. ${ }^{5,8}$

Vaginal delivery is preferred; there is no spesific indication for cesare an delivery in GD but cesarean section rate is higher in GD because of orthopedic considerations. ${ }^{5}$ Our patient delivered with cesarean section because of breech presentation. Breast feeding should be limited for six months because of bone demineralization. ${ }^{4}$ Vitamin D supplementation should be continue during breast feeding.

For the patients who are suffering from GD in the age of child bearing, pregnancy is not contrindicated. ERT with imiglucerase should not be interrupted.

No adverse effect or no malformation reported on fetuses due to ERT. However long term followup in larger cohort groups needed to assess effects of ERT with imiglucerase on pregnancy and baby. 


\section{REFERENCES}

1. Whitfield PD, Nelson P, Sharp PC, Bindloss $\mathrm{CA}$, Dean C, Ravenscroft EM, et al. Correlation among genotype, phenotype, and biochemical markers in Gaucher disease: implications for the prediction of disease severity. Mol Genet Metab 2002;75(1):46-55.

2. Beutler $\mathrm{E}$, Grabowski GA. Gaucherdisease. In: Scriver CR, Beaudet AL, Sly WS, Valle D, eds. Metabolic and Molecular Bases of Inherited Disease. 8th ed. New York: McGraw-Hill; 2001. p.3635.

3. Grabowski GA. Recent clinical progress in Gaucher disease. Curr Opin Pediatr 2005;17(4):519-24.
4. Granovsky-Grisaru S, Belmatoug N, vom Dahl S, Mengel E, Morris E, Zimran A. The management of pregnancy in Gaucher disease. Eur J Obstet Gynecol Reprod Biol 2011;156 (1):3-8.

5. Elstein $Y$, Eisenberg V, Granovsky-Grisaru S, Rabinowitz R, Samueloff A, Zimran A, et al. Pregnancies in Gaucher disease: a 5-year study. Am J Obstet Gynecol 2004;190(2):435-41.

6. Weinreb NJ, Charrow J, Andersson HC, Kaplan $\mathrm{P}$, Kolodny EH, Mistry $\mathrm{P}$, et al. Effectiveness of enzyme replacement therapy in 1028 patients with type 1 Gaucher disease after 2 to 5 years of treatment: a report from the
Gaucher Registry. Am J Med 2002;113(2): 112-9.

7. Sims KB, Pastores GM, Weinreb NJ, Barranger J, Rosenbloom BE, Packman S, et al. Improvement of bone disease by imiglucerase (Cerezyme) therapy in patients with skeletal manifestations of type 1 Gaucher disease: results of a 48-month longitudinal cohort study. Clin Genet 2008;73(5):430-40.

8. Elstein D, Granovsky-Grisaru S, Rabinowitz $R$, Kanai R, Abrahamov A, Zimran A. Use of enzyme replacement therapy for Gaucher disease during pregnancy. Am J Obstet Gynecol 1997;177(6):1509-12. 